\title{
Risk Assessment for Accounting Professional Liability Insurance 1
}

Şerafettin SEVIM, Department of Business Administration, Faculty of Economics and Administrative Sciences, Dumlupinar University, Turkey; e-mail: serafettin.sevim@dpu.edu.tr

Birol YILDIZ, Department of Business Administration, Faculty of Economics and Administrative Sciences, Eskisehir Osmangazi University, Turkey; e-mail: byildiz@ogu.edu.tr

Nilüfer DALKILIÇ, Department of Insurance and Risk Management, School of Applied Sciences, Dumlupinar University, Turkey; e-mail: nilufer.dalkilic@dpu.edu.tr

\section{Muhasebe Mesleği Sorumluluk Sigortaları için Risk Değerlemesi²}

\begin{abstract}
In this study, litigation risk factors were determined for accounting professional liability insurance and an artificial neural network was developed to determine the litigation risks. A training data set comprised of data from 201 policies was used to train an artificial neural network. The performance of the artificial neural network model was then assessed using a test data set comprised of data from 100 policies. In the research, a litigation risk estimation model was formed for liability insurance via an artificial neural network model. By comparing the litigation risks occurring in accounting professional liability insurance to those foreseen by the artificial neural network system, it was determined that the results were quite consistent. It was also determined that the realized results and the risks foreseen in the artificial neural network model provided data close to the real values and that the artificial neural network model could foresee the litigation risks in accounting professional liability insurance with a $99 \%$ success rate.
\end{abstract}

Keywords $\quad$ : Insurance Industry, Litigation Risk, Accounting Professional Liability Insurance, Risk Assessment, Artificial Neural Network.

JEL Classification Codes : $\quad$ C45, G22, M41.

$1 \quad$ This article is the revised and extended version of the paper presented in "First International Annual Meeting of Sosyoekonomi Society" which was held by Sosyoekonomi Society and CMEE - Center for Market Economics and Entrepreneurship of Hacettepe University, in Munich/Germany, on October 29-30, 2015.

2 Bu makale Sosyoekonomi Derneği ile Hacettepe Üniversitesi Piyasa Ekonomisini ve Girişimciliği Geliştirme Merkezi tarafindan Almanya'nın Münih şehrinde, 29-30 Ekim 2015 tarihlerinde düzenlenen "Birinci Uluslararası Sosyoekonomi Derneği Yıllık Buluşması"nda sunulan çalışmanın gözden geçirilmiş ve genişletilmiş halidir. 


\section{$\ddot{\mathbf{O} z}$}

Çalışmada muhasebe mesleği sorumluluk sigortalarının hukuki risk faktörleri belirlenerek, hukuki risklerini değerlendiren yapay sinir ağı modeli geliştirilmiştir. Çalışmada yapay sinir ağı yöntemi uygulanmıștır. Muhasebe mesleği sorumluluk sigortalarında gerçekleșen hukuki riskle, yapay sinir ağı yönteminin öngördüğü hukuki risk mukayese edildiğinde sonuçların oldukça uyumlu olduğu tespit edilmiştir. Gerçekleşen sonuçlar ile yapay sinir ağı modelinden elde edilen sonuçların gerçek değerlere çok yakın çıktılar verdiği ve yapay sinir ağ mesleği sorumluluk sigortalarının hukuki risklerinde doğru öngörüde bulunduğu tespit edilmiştir.

Anahtar Sözcükler $\quad$ : Sigorta Sektörü, Muhasebe Mesleği Sorumluluk Sigortaları, Risk Değerlemesi, Yapay Sinir Ağları.

\section{Introduction}

Accounting professional liability insurance is common in developed countries. It is a new insurance domain in Turkey, having started in 2007, and it has since become more common and more developed due to the interest from accountants.

The aim of this study was to foresee the litigation risks for accounting professional liability insurance by developing an artificial neural network model that assesses the litigation risk factors in accounting professional liability insurance. In the study, insurance application forms for international and national insurance companies for accounting professional liability insurance was analyzed as data resources to determine the litigation risk factors. A risk assessment model was developed using the artificial neural network method to assess and foresee the litigation risks for the liability insurance of the accountancy profession. The test data acquired through the model were compared with the actual data, and it was concluded that the model was accurate at the rate of $99 \%$.

\section{Previous Research}

Professional liability insurance exists in the literature as insurance for "malpractice" or "failure and negligence." This type of insurance bears the responsibility of paying for the damage caused by the insured while performing his/her profession (Dorfman, 1991: 174; Vaughan \& Vaughan, 2007: 527).

The "liability" in professional liability insurance refers to the fact that it protects the insurer against damage from his/her failure or negligence and that it covers the court expenses if a customer sues (Shapiro, 2004: 59). The accountancy profession is always intertwined with liability (Palmrose, 1987: 90). Members of the accountancy profession are liable for the financial statements that they approve (Dorfman, 1991: 176). Any negligence in preparing financial statements or auditing could lead to a court case and compensation against a member of the accountancy profession. 
The professional activities of the members of the accountancy profession involve litigation risks that lead to court cases in which their clients seek compensation for reasons such as failures, negligence, false representation, or violation of privacy. The risks arising from SSK (Social Security) premiums, taxes, tax penalties, late fees and default interest payments of the members of the accountancy profession by joint liability are also included in the litigation risks (TSRŞB, 2010). When insured by professional liability insurance, the members of the accountancy profession transfer the likelihood of paying for the damage caused by litigation risks to the insurance companies (Linville, 2001: 69).

Insurance companies collect a wide range of information through insurance application forms and use this information to decide upon the factors regarding the litigation risks. Linville and Thorton (2001) claim that there is a standard in defining the litigation risk factors, and they are advocates of the insurance companies' asking for information from the insured through the insurance application forms. In their study, they analyzed the insurance application forms of 8 insurance companies that provide professional liability insurance to the accountancy profession and formed litigation risks from these insurance application forms in two groups: customer-specific risk factors and firm-specific risk factors.

The litigation risk factors in our study were based on Linville and Thorton's (2001) study, in which they analyzed the information in the professional liability insurance application forms of 7 insurance companies (CPA Mutual, CNA, Zurich-American, Coregis/Wesport, Design Professionals, Safeco, Preferred National and Camico). Our study analyzed the insurance application forms for accounting professional liability insurance from 10 international insurance companies (AIG, Comico, AICA, Fireman's Fund, Insight, General Stars, National Casualty, Phidelphia, Cpa Mutual, AICPA) and 5 insurance companies in Turkey (Chartis, Ak, Anadolu, Ergo İsviçre, Ray). The insurance application forms ranged from 5 to 10 pages, in which detailed information was sought. In our study, the information from 5 insurance companies that provide professional liability insurance in the accountancy profession was compared.

The information in the application forms was analyzed using the studies in the literature on litigation risks, and the litigation risk factors were formed. The litigation risk factors for accounting professional liability insurance were divided into two categories: customer-specific risk factors and firm-specific risk factors.

\subsection{Customer-specific Litigation Risk Factors for Professional Liability Insurance in the Accountancy Profession}

The customers with the customer-specific litigation risk factors are those whom the members of accountancy profession deal with. Table 1 shows a literature review of the customer-specific litigation risk factors and how these factors are captured in the information in the application forms of insurance companies. The customer specific litigation risk factors were defined as 9 variables: customer size, number of customers, sector of customers, financial challenges of customers, corruption of customers, free float of customers, income 
rate of customers, market value of customers and service duration. The literature review is compared below.

Table: 1

Comparison of the Literature Review of Customer-Specific Litigation Risk Factors With Insurance Application Form Information

\begin{tabular}{|c|c|c|c|}
\hline $\begin{array}{l}\text { Customer-Specific } \\
\text { Litigation Risk Factors }\end{array}$ & Literature Review & $\begin{array}{c}\text { Application Form Information } \\
\text { of Internationally Operating } \\
\text { Insurance Companies }\end{array}$ & $\begin{array}{c}\text { Application Form Information } \\
\text { of Insurance Companies } \\
\text { Operating in Turkey } \\
\end{array}$ \\
\hline Size of Customer & $\begin{array}{l}\text { Schult and Gustavson (1978) } \\
\text { St. Pierre and Anderson (1984) }\end{array}$ & Five insurance companies & 1 insurance company \\
\hline Number of Customers & Linville (2001) & One insurance company & Not Specified \\
\hline Customer Sector & $\begin{array}{l}\text { Stice (1991) } \\
\text { St. Pierre and Anderson (1984) } \\
\text { Linville (2001) }\end{array}$ & Six insurance companies & 1 insurance company \\
\hline Financial Difficulties of Customer & $\begin{array}{l}\text { Schult and Gustavson (1978) } \\
\text { Carcello and Palmrose (1994) } \\
\text { Lys and Watts (1994) } \\
\text { Stice (1991) }\end{array}$ & Four insurance companies & Not Specified \\
\hline $\begin{array}{l}\text { Management Corruption } \\
\text { in Customer }\end{array}$ & $\begin{array}{l}\text { Carcello and Palmrose (1994) } \\
\text { Bonner, Palmrose, Young (1998) } \\
\text { Palmrose (1987) } \\
\text { Ferguson and Majid (2003) }\end{array}$ & Not Specified & Not Specified \\
\hline Openness of Customer to Public & $\begin{array}{l}\text { Bonner, Palmrose, Young (1998) } \\
\text { Lys and Watts (1994) } \\
\text { Stice (1991) } \\
\text { Simunic and Staein (1996) }\end{array}$ & Not Specified & Not Specified \\
\hline $\begin{array}{l}\text { Ratio of Customer in } \\
\text { Insurance Firm Income }\end{array}$ & $\begin{array}{l}\text { Lys and Watts (1994) } \\
\text { Stice (1991) }\end{array}$ & Two insurance companies & Not Specified \\
\hline Market Value of Customer & Stice (1991) & Not Specified & Not Specified \\
\hline Duration of Service to Customer & St. Pierre and Anderson (1984) & Two insurance companies & Not Specified \\
\hline
\end{tabular}

Size of Customer: This risk factor is assessed through the annual returns and the number of employees of the customer. In the literature, the effect of the size of customer on the litigation risk is controversial.

St. Pierre and Anderson (1984) concluded that the size of the customer does not have an effect on the litigation risk (St. Pierre \& Anderson, 1984: 248). Schult and Gustavson (1978), however, determined that there is a positive relationship between an increase in the size of the customer and an increase in the litigation risk (Schult \& Gustavson, 1978: 626). In the insurance application forms analyzed in this study, the risk factor of size of the customers of 5 internationally operating insurance companies and 1 insurance company operating in Turkey was captured.

Number of Customers: Linville (2001) alleged in his study that the number of customers is related to litigation risk. It was proposed that when the number of customers increases, so does the attention required for each customer; therefore, service quality decreases and it is more difficult to track and assess each customer. Linville (2001) claimed that when the number of customers increases, so does the litigation risk (Linville, 2001: 65). In the insurance application forms analyzed in our study, while one internationally operating insurance company asked for the number of customers, the insurance companies that are operating in Turkey did not. 
Customer Sector: Stice (1991) found that the customer sector is an important factor in the cases against members of accountancy profession (Stice, 1991: 528). St. Pierre and Anderson (1984) found that the customer sector affects litigation risk. In their study, the customer sectors of finance, insurance, real estate or manufacturing more strongly affected the litigation risk (St. Pierre \& Anderson, 1984: 256-257). Linville (2001) claimed that an increase in the variety of the customer sectors required knowing the reporting standards for each sector and the accountancy applications. For this reason, it was concluded that the customer sector affects the litigation risk (Linville, 2001: 65). In the insurance application forms analyzed in our study, 6 internationally operating insurance companies and 1 insurance company operating in Turkey sought information on the customer sector.

Financial Difficulties of Customers: Schult and Gustavson (1978) stated that when the customers are financially weak, the court cases and the compensation amounts sought against the accountancy professional will be high along with the litigation risk (Schult \& Gustavson, 1978: 633). Carcello and Palmrose (1994) claimed that because bankrupt customers frequently sue accountancy professionals, bankruptcy affects litigation (Carcello \& Palmrose; 1994: 27-28). Lys and Watts (1994) concluded that the financial difficulties of the customer or firm have an effect on court cases, but they did not explain these effects (Lys $\&$ Watts, 1994: 92). Palmrose (1987) researched the effect of firm bankruptcy on court cases and found that the deterioration of the financial condition increases court cases but also determined that most of the firms that were unsuccessful because of financial difficulties did not sue the accountancy firms (Palmrose, 1987: 101). Stice (1991) concluded that the financial condition of the customer affects court cases (Stice, 1991: 532). In the insurance application forms analyzed in our study, 4 internationally operating insurance companies focused on the financial difficulties factor in terms of a state of insolvency and bankruptcy whereas no insurance companies operating in Turkey addressed the financial difficulties risk factor.

Management Corruption in Customers: Carcello and Palmrose (1994) asserted that management corruption in customers is a crucial risk factor for litigation risk (Carcello \& Palmrose; 1994: 19-20). Bonner, Palmrose, and Young (1998) supported the hypothesis that invented proceedings and corruption on financial statements increase auditing court cases (Bonner et al. 1998: 527). Palmrose (1987) investigated management corruption in court cases and found that management corruption was determined in most of the cases opened by bankrupted customers (Palmrose, 1987: 101). Ferguson and Majid (2003) concluded that management corruption did not have any effect on the court decision (Ferguson \& Majid, 2003: 363). In the insurance application forms analyzed in our study, neither the internationally operating insurance companies nor those operating in Turkey included the management corruption litigation risk factor.

Openness of Customers to Public: Bonner et al. (1998) determined that the risk factor of the openness of customers to the public has no effect on litigation risk (Bonner et al, 1998: 527). Lys and Watts (1994) stated that the share performance and the share size of the customers have an effect on the court cases against the members of accountancy (Lys \& 
Watts, 1994: 92). Stice (1991) found that factor of the openness of customers to the public has a relationship with the court cases against the members of accountancy (Stice, 1991: 516). Simunic and Staein (1996) revealed that the factor of the openness of customers to the public affects litigation risk (Simunic \& Staein, 1996: 125). In the insurance application forms analyzed in our study, the factor of the openness of the customers to the public was not explored by either the internationally operating insurance companies or those operating in Turkey.

Ratio of Customers in the Insurance Firm Income: Lys and Watts (1994) concluded that a high ratio of customers in the insurance firm income affects the likelihood of court cases against insurance firms (Lys \& Watts, 1994: 65). Stice (1991) alleged that an increase in the customer income increases the likelihood of court cases against the members of the accountancy profession (Stice, 1991: 516). In the insurance application forms analyzed in our study, while two internationally operating insurance companies requested information on this factor, those operating in Turkey did not.

Market Value of Customers: Stice (1991) concluded that the market value of the customers affects the likelihood of court cases against the members of the accountancy profession (Stice, 1991: 532). Stice (1991) alleged that when the market value of the customers is high, so is the likelihood of court cases (Stice, 1991: 516). In the insurance application forms analyzed in our study, neither the internationally operating insurance companies nor those operating in Turkey asked for information on the market value of the customers.

Duration of Service to Customer: St. Pierre and Anderson (1984) concluded that the accountancy firm's duration of service to the customer affects risk and that 3 years or less duration of service to the customer increases the litigation risk (St. Pierre \& Anderson, 1984: 256). In the insurance application forms analyzed in our study, two internationally operating insurance firms asked for the duration of service to the customers. The insurance companies operating in Turkey did not ask for any information on the duration of service to customers.

\subsection{Accountancy Firm-Specific Litigation Risk Factors in Professional Liability Insurance for the Accountancy Profession}

Accountancy firm-specific litigation risk factors were considered as the following variables: size of the accountancy firm (number of employees, firm income), court case cycle, quality of the accountancy firm. Analyzing the insurance application forms, the following variables were considered to be variables not existing in the literature: foundation date, services, authorization that customers give to the firm, previous insurances and rejected insurance applications.

Size of Accountancy Firm: The size of the accountancy firm is assessed as directly proportional to the number of employees and the accountancy firm income. Linville 
and Thorton (2001) claimed that there is no proof about the effect of the size of the accountancy firm, in terms of the information about the number of employees and gross income, on litigation risk (Linville \& Thorton, 2001: 99-101).

Schultz and Gustavson (1978) determined that there is a positive relationship between the size of the accountancy firm and the increase in risk (Schult \& Gustavson, 1978: 626). Bonner et al. (1998), claiming that large accountancy firms provide higher quality service, concluded that large accountancy firms have a lower likelihood of court cases than small accountancy firms (Bonner et al., 1998: 512). Frencis, Philbrick, Schipper (1994) have found that the relationship between firm size and legal risks, they also found that the degree of influence the proceedings or the rate of occurrence of this relationship (Frencis et al., 1994:140). Lys and Watts (1994) could not find any effect from the size of the accountancy firm on court cases, but they stated that this conclusion could have arisen from an insufficient dispersion of the accountancy firm size factor (Lys \& Watts, 1994: 92). Palmrose (1988) analyzed the litigation risk of 8 large and 8 small accountancy firm in two groups and concluded that small accountancy firms have a greater court case likelihood than large ones (Palmrose, 1988: 72). Ferguson and Majid (2003) concluded that, compared to small accountancy firms, there is more likelihood of court cases against the large firms (Ferguson \& Majid, 2003: 363).

In the insurance application forms analyzed in our study, the employee number of 10 internationally operating insurance firms and 4 insurance firms operating in Turkey was requested. The income of the accountancy firm was requested by 9 internationally operating insurance firms and 3 insurance firms operating in Turkey. The income was analyzed in 5 groups: income for two years before the last fiscal year, in the year before the last fiscal year, in the last fiscal year, in the current fiscal year (projected), in the following fiscal year (projected).

Table: 2

\section{Comparison of the Literature Review of Accountancy Firm-Specific Litigation Risk} Factors with Insurance Application Form Information

\begin{tabular}{|c|c|c|c|}
\hline $\begin{array}{l}\text { Accountancy Firm-Specific } \\
\text { Litigation Risk Factors }\end{array}$ & Studies & $\begin{array}{c}\begin{array}{c}\text { Application Form Information } \\
\text { of Internationally Operating } \\
\text { Insurance Companies }\end{array} \\
\end{array}$ & $\begin{array}{c}\text { Application Form Information } \\
\text { of Insurance Companies } \\
\text { Operating in Turkey }\end{array}$ \\
\hline \multirow[b]{2}{*}{$\begin{array}{l}\text { Size of Accountancy Fim } \\
\text { Number of employees and firm income }\end{array}$} & \multirow[b]{2}{*}{$\begin{array}{l}\text { Schult and Gustavson (1978) } \\
\text { Bonner, Palmrose, Young (1998) } \\
\text { Francis, Philbrick, Schipper (1994) } \\
\text { Lys and Watts (1994) } \\
\text { Palmrose (1988) } \\
\text { Ferguson and Majid (2003) } \\
\text { Linville and Thorton (2001) }\end{array}$} & 10 insurance companies & 4 insurance companies \\
\hline & & 9 insurance companies & 3 insurance companies \\
\hline Court Case Cycle & Schult and Gustavson (1978) & 9 insurance companies & 3 insurance companies \\
\hline Quality of Accountancy Firm & $\begin{array}{l}\text { Palmrose (1988) } \\
\text { Simunic and Staein (1996) }\end{array}$ & 3 insurance companies & Not specified \\
\hline Foundation Date of Accountancy Firm & Not specified & 10 insurance companies & 5 insurance companies \\
\hline Services & Not specified & 9 insurance companies & 2 insurance companies \\
\hline Previous Insurances & Not specified & 10 insurance companies & 4 insurance companies \\
\hline Rejected Insurance Applications & Not specified & 9 insurance companies & 4 insurance companies \\
\hline
\end{tabular}


Court Case Cycle: Schult and Gustavson (1978) concluded that the court case cycle risk factor does not have a significant effect on the litigation risk (Schult and Gustavson, 1978: 626). The court case cycle risk factor is included in the insurance application forms. In the insurance application forms analyzed in our study, 9 internationally operating insurance firms asked whether the firms appealed for compensation from the accountancy firm or one of its previous shareholders. For the insurance companies operating in Turkey, three requested the court cases and compensation against the firm in terms of professional liability in the last five years.

Quality of the Accountancy Firm: Palmrose (1988) concluded that a higher quality of accountancy firm leads to a lower court case likelihood and vice versa (Palmrose, 1998: 55). Simunic and Staein (1996) claimed that the litigation risk increases if the accountancy firms provide an underrated auditing service (Simunic \& Staein, 1996: 132). In the insurance application forms analyzed in our study, three internationally operating insurance companiesrequested quality certificates from the accounting firms whereas no such request exists in the insurance application forms for the insurance firms operating in Turkey.

Foundation Date of the Accountancy Firm: In the litigation risk literature, there is not a factor for the foundation date of the accountancy firm as its start date, but the foundation date factor is considered to be a significant factor in the insurance application forms. In the insurance application forms analyzed in our study, both the internationally operating insurance firms and those operating in Turkey requested the foundation date of the accountancy firm.

Services: In the litigation risk literature, there is not a factor for services provided by the members of the accountancy profession, but they are regarded as a significant factor in the insurance application forms and the percent of each service from which the accountancy firm received its annual return is requested. In the insurance application forms analyzed in our study, nine internationally operating insurance firms and two insurance companies operating in Turkey requested the annual share of the services comprising the gross income.

Previous Insurances: In the litigation risk literature, there is not a factor for previous insurance. In the insurance application forms analyzed in our study, ten internationally operating insurance firms and four insurance companies operating in Turkey requested information on previous insurance and damages in detail.

Rejected Insurance Applications: In the litigation risk literature, there is not a factor for rejected insurance applications, but a rejected insurance application is regarded as a significant factor by both the internationally operating insurance companies and those operating in Turkey. In the insurance application forms analyzed in our study, nine internationally operating insurance firms and four insurance companies operating in Turkey identified the variable of rejected insurance applications. 


\section{Methodology}

Artificial neural networks are frequently preferred and practically applied in many areas (Paliwal \& Kumal, 2009: 2). This method is a type of information processing system developed from neural networks composed of biological neurons. Artificial neural networks have a mathematical structure and the outputs are gained through mathematical modeling (Ellacott \& Bose, 1996: 10; Fausett, 1994: 3). Artificial neural networks generally form accepted estimation functions: a model is developed out of the relationships between the variables gained from the previous data and tested. Artificial neural networks can also model nonlinear data (Shapiro \& Jain, 2003: 53).

In the studies carried out using the artificial neural network method, insurance risk is classified and assessed (Shapiro, 2002: 1). The assessment of the insured is significant in the insurance process. The acceptance or the renewal of insurance applications is determined according to the risk assessment of the insured (Lin, 2009: 6914). Insurance companies require risk assessment models that are fast and reliable for insurance decisions. "Artificial Neural Networks" are one important method that is used in the assessment of insurance risks. In insurance, by determining whether the risks are acceptable or not, the decision making process for being insured is made efficiently (Craig, 1995: 9; Joblonowski, 1998: 103; Tauhet, 1997: 31). Table 3 summarizes the research subjects in the insurance risk assessment with artificial neural networks.

Table: 3

\section{The Research in Insurance Risk Assessment using Artificial Neural Networks}

\begin{tabular}{|l|l|}
\hline Research & Research Subjects \\
\hline Tu (1993) & $\begin{array}{l}\text { Estimation modeling for the duration in the intensive care unit according to } \\
\text { heart operation risk class }\end{array}$ \\
\hline Saemundsson (1996) & $\begin{array}{l}\text { Modeling of treatment duration for dental care insurance according to risk } \\
\text { class }\end{array}$ \\
\hline Lowe and Pryor (1996) & Assessing the risks in insurance policies for the pricing of insurance policies \\
\hline $\begin{array}{l}\text { Vaughn, Ong and Cavill } \\
\text { (1997) }\end{array}$ & Classifying the standard and nonstandard risks of life insurance \\
\hline $\begin{array}{l}\text { He, Wang, Graco and } \\
\text { Hawkins (1997) }\end{array}$ & $\begin{array}{l}\text { High and low risk two-group modeling on health profiles developed by the } \\
\text { Australia health insurance commission }\end{array}$ \\
\hline Ismael (1999) & Modeling of advanced heart failure in terms of insurance \\
\hline $\begin{array}{l}\text { Yeo, Smith, Willis and } \\
\text { Brooks (2000) }\end{array}$ & Assessing the risks of vehicle insurance between 1990 and 1998 \\
\hline $\begin{array}{l}\text { Smith, Willis and Brooks } \\
\text { (2000) }\end{array}$ & Risk classification of the motor own damage insured between 1996 and 1998 \\
\hline Hsu, Lin and Yang (2008) & Risk assessment modeling in health insurance \\
\hline Lin (2009) & Risk assessment in fire insurance \\
\hline Shah and Guez (2009) & Modeling of death risk in life insurance \\
\hline
\end{tabular}

Treatment duration has an important effect on cost for insurance companies. Tu (1993) and Saemundson (1996) used the artificial neural network method to model treatment duration in insurance. Tu (1993) modeled the patients having heart treatment according to 
risk groups and estimated their treatment durations. Saemundson (1996) modeled the treatment determination and duration in dental disease using the artificial neural network method (Shapiro, 2002: 4).

Lowe and Pryor (1996) assessed the risks in insurance policies for pricing insurance policies using artificial neural networks and the genetic algorithm method. Successful results were obtained for risk premium calculations for insurance premiums using the artificial neural networks method (Lowe \& Pryor, 1996: 434).

Vaughn, Ong and Cavill (1997), using multi-layer artificial neural networks, classified the standard and nonstandard risks in life insurance and developed an effective method for life insurance to assess risks (Vaughn et al., 1997: 201).

He, Wang, Graco and Hawkins (1997) studied the health profile developed by the Australia health insurances commission using the artificial neural networks method. The high- and low-risk customer groups were modeled for health insurance. Whether the patients were classified in the high- or the low-risk customer group was estimated (He et al., 1997: $335)$.

Ismael (1999) modeled the death risk of heart disease using the artificial neural network method and developed a successful model to estimate the time of death for these patients in terms of risk factors (Shapiro, 2002: 4).

Yeo, Smith, Willis and Brooks (2000) modeled the coverage and pricing of vehicle insurance by assessing vehicle insurance risks between 1990 and 1998 (Yeo et al., 2002: 1198).

Smith, Willis and Brooks (2000) modeled the risk classification of the motor own damage insured who owned insurance between 1996 and 1998. These authors used an artificial neural network and assessed the risks of the insured in terms of the decision to renew or terminate their insurance. It was not only claimed that this assessment would affect insurance companies and positively reflect directly on their profitability, but it was also emphasized that risk assessment is crucial on the basis of policy (Smith et al., 2000: 532).

Hsu, Lin and Yang (2008) developed a risk assessment model in health insurance using artificial neural networks. The assessment was performed using artificial neural networks with 7 risk factors. The health expenditures were estimated according to the risk factors in the model. It was asserted through the model developed that the higher-risk insured should pay higher premium (Hsu et al., 2008: 642).

Lin (2009) conducted a risk assessment for fire insurance using artificial neural networks. The study aimed to determine fire insurance premiums according to risks. Efficiency in the determination of premiums was achieved through risk assessment. To determine the risk premium accurately, 435 different risk groups within the Taiwan fire 
insurance rates were modeled using artificial neural networks. It was concluded that artificial neural networks are an efficient method for risk assessment (Lin, 2009: 6917).

Shah and Guez (2009) constructed a Lee-Carter model used in death risk estimation for life insurance policies using the artificial neural networks method. The artificial neural networks method performed better than the Lee-Carter model and the death risk was estimated with a $95 \%$ success rate using the individual health conditions of the insured (Shah \& Guez, 2009: 535).

\section{Data and Model}

To determine the risk of the insured, there are various risk factors that are regarded as variables. In artificial neural network management, processing the risk factors as inputs, the outputs are produced to determine the risk. The model allows us to either accept or reject the risk for the insurance companies. Previous policy data are required to use as a training data set to form the model. Making use of the previous policy data, risk can be determined in individual policies with the artificial neural networks (Lowe \& Pryor, 1996: 423).

Our study aimed to develop an assessment model for the litigation risks of liability insurance for the accountancy profession. The liability insurance for the members of the accountancy profession involves litigation risk factors in two groups: customer-specific and firm-specific. Unknown and challenging relationships exist with litigation risk factors. The artificial neural network method can model these relationships, thanks to its nonlinear structure and, thus, it can present a risk assessment that models the unexplainable relationships between risk factors. Therefore, the artificial neural network method was used in the study.

To assess the insurance risk, damage data are also needed in addition to the policy data. In this research, the insurance risk was assessed by modeling the previous policies and the damage data statistically using an artificial neural network. The insurance application form data were collected from various insurance firms. In the artificial neural networks model, data from 301 accounting professional liability insurance policies from insurance firms operating in Turkey were used, 202 of which were no damage policies whose litigation risks had not occurred and 99 of which were damaged policies whose litigation risks had occurred.

In the artificial neural networks model, the data set should be able to represent the actual data. The data were divided into two groups: training and test groups (Y1ld1z, 2001). For the training data set, 152 no damage and 49 damaged policies were used. For the test data set, 50 no damage and 50 damaged policies were used.

Deciding on the artificial neural network architecture, the training data set comprised of data from 201 policies were used to train the artificial neural network. The 
performance of the artificial neural network model was assessed using the test data set comprised of data from 100 policies. In the research, a litigation risk estimation model was formed for liability insurance via the artificial neural network model.

The litigation risk factors were formed by assessing the insurance application forms of the insurance firms. Because insurance firms do not keep detailed insurance application forms, the data about customer specific risk factors could not be found for the study. For this reason, the risk factors of the liability insurance for the accountancy profession were assessed in the study as company-specific litigation risk factors.

The variables that determine the litigation risk were considered to be input variables for the estimation model. The risk factors that determine the litigation risk were gathered from the information in the insurance application forms. There were 11 factors considered to be litigation risk factors: the title of the accountant, the foundation year of the insured accountancy firm, the corporate tax percentage in the last completed year (stoppage tax and/or income tax returns), the financial turnover in the last completed year, the current financial turnover, whether the insured works alone with no employees, whether an accounting professional liability insurance will be renewed in five years, the cancellation of accounting professional liability insurance and the rejection of the renewing request and the premium. To support the artificial neural network model, the premium, the title of the member of the profession (as an independent accountant, an independent accountant and financial advisor or a certified public acountant) and the damage were assessed from policy data. The damage data were considered to be output data. The output value was coded as 0 or 1: 0 being a no damage policy whose litigation risk had not occurred and 1 being a damage policy whose litigation risk had occured.

For the artificial neural network model, nntool (Neural Network Toolbox) was used in the Matlab 2006 (6.5 version) program. Because there are eleven independent variables in the model, there are eleven input neurons that enter the input variables into the network. There is one neuron in the output layer for the dependent variable that yields the network output. As a result of trials carried out with various numbers of secret neurons and secret layer numbers, it was observed that a network architecture composed of a mono secret layer yielded better results. An artificial neural network model was formed on this secret layer using ten neurons. A ten layered feed-forward artificial neural network was chosen as the network model.

Details of the model are below:

$\begin{array}{ll}\text { Number of Layers } & : 2 \\ \text { Number of Neurons in the Layers } & : 10-1 \\ \text { Network Type } & : \text { Feed Forward Artifical Neural Network } \\ \text { Training Function } & : \text { TRAINLM }\end{array}$




\section{Performance Function}

Communication Function

Adaptation Learning Function
: MSE

: PURELIN

: LEARNGD

One of the factors affecting the performance of the artificial neural network is the training algorithm. "trainlm" was chosen as the training algorithm because the best result was gained from the network structure in which the Levenberg-Marquart (trainlm) algorithm was used as a training algorithm during trials. After various trials, the training rate was taken as 0.2 . The artificial neural network to be used in the study was formed as Network1 in specified features. Fig 1 shows the structure of the artificial neural network model.

\section{Figure: 1}

\section{Artificial Neural Network Model}

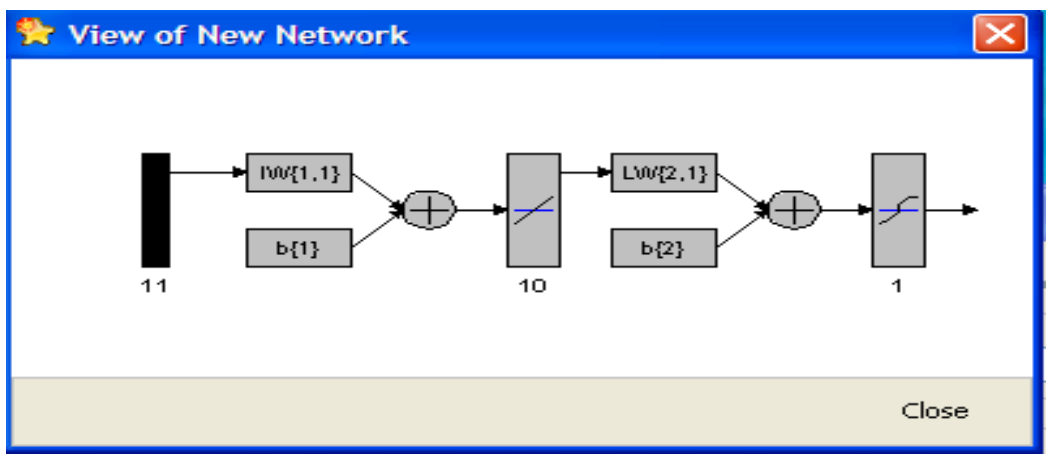

The linear addition function applied in the artificial neural network model is composed of 10 neurons on the secret layer with 11 input and one output as follows. In the formula, $\mathrm{X}$ expresses input, while $\mathrm{W}=$ loads, $\mathrm{Y}=$ sum of weight and $\mathrm{n}=$ total input number (Trippi \& Turban, 1996: 8).

$$
Y_{i}=\sum_{j}^{n} X_{i} W_{i j}
$$

The same activation function exists in the neurons on the secret layer and the output layer. The activation function applied in the artificial neural network model is as follows. In the formula, y expresses the input value, while $\mathrm{YT}=$ normalized values of the $\mathrm{y}$ value. The activation function will allow the formation of output values between 0 and 1 (Trippi \& Turban, 1996: 8). 


$$
Y_{T}=\frac{1}{1+e^{-y}}
$$

The training data set is used for training and the development of the artificial neural network model. The test data set is used to measure the performance of the artificial neural network. The data should be normalized for the artificial neural network to put the data sets, composed of the training and test data sets, into operation. The sigmoid function was chosen in our study to be the activation function for the secret and the output layers. The data were normalized with the following function presented below, taking the $[0,1]$ interval into account. In the formula, Vn expresses the normalized data while $\mathrm{x}$ : original data, Xmax: maximum value throughout the line or column and Xmin: minimum value throughout the line or column. The normalization formula used in the artificial neural network model is as follows:

$$
V n=0.8 \frac{X X_{\min }}{X X_{\max }} \div+0.1
$$

The data were coded without using any verbal expressions. No damage policies were coded as 0 , while damaged policies were coded as 1 . The coded data were then normalized. Using the policy data, the test data composed of damaged and no damage policies were predicted. In the artificial neural network, the sigmoid activation function was used and the learning algorithm was MLN. The training rate was 0.5 MLN. Accordingly, a training performance value of 0.00203266 was achieved in the network as a result of 1000 epochs. The training and the test data were normalized between the values 0.1 and 0.9 .

The error values for the training and the test data sets can be seen in Figures 2 and 3 below. 
Figure: 2

The Relationship between the Actual Values and the Values Calculated with the Artifical Neural Network Model for the Training Data Set

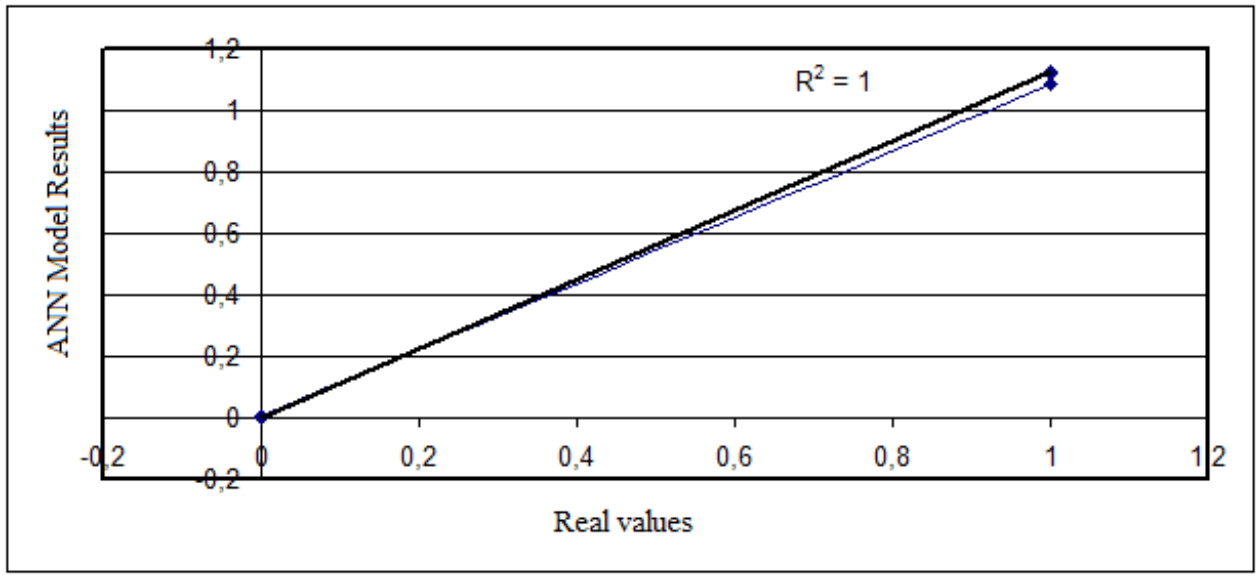

As seen in Figure 2, the error value between the actual data and the data calculated with the artificial neural network for the training data set was found to be 0,997 .

Figure: 3

The Relationship between the Actual Values and the Values Calculated with the Artifical Neural Network Model for the Test Data Set

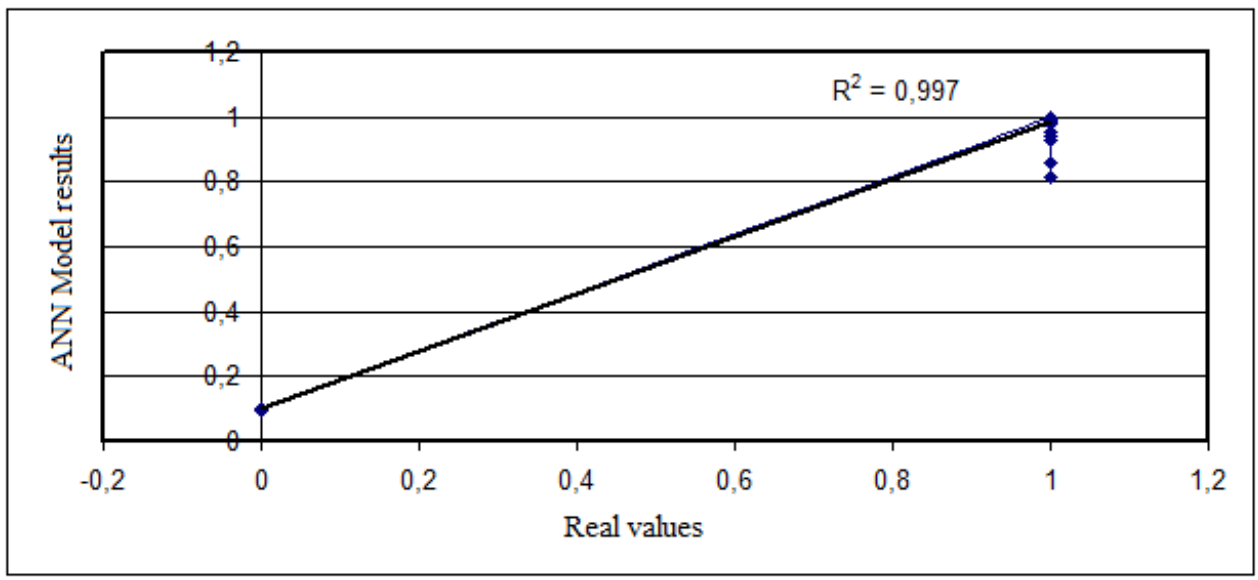

As seen in Fig 3, the error value between the actual data and the data calculated with the artificial neural network for the test data set was found to be 1 . The actual values of 
the insurance policies and the estimated values acquired in the artificial neural network model are in Table 4 below.

Table: 4

\section{Comparison of the Test Data from the Artificial Neural Network Model with the Actual Data}

\begin{tabular}{|c|c|c|c|c|}
\hline $\begin{array}{c}\text { Actual } \\
\text { Normalized } \\
\text { Test Data }\end{array}$ & $\begin{array}{l}\text { Artificial Neural Network } \\
\text { Results with Purelin Option }\end{array}$ & $\begin{array}{c}\text { Actual Reverse } \\
\text { Normalized Data }\end{array}$ & $\begin{array}{l}\text { Reverse Normalized Data of the Artificial Neural } \\
\text { Network Model Results with Purelin Option }\end{array}$ & $\begin{array}{l}\text { Results Rounded } \\
\text { to the Nearest }\end{array}$ \\
\hline 0,1 & 0,10 & 0 & 1,125 & 1 \\
\hline 0,1 & 0,10 & 0 & 0,004125 & 0 \\
\hline 0,1 & 0,10 & 0 & 0,001 & 0 \\
\hline 0,1 & 0,10 & 0 & 0,00225 & 0 \\
\hline 0,1 & 0,10 & 0 & 0,001625 & 0 \\
\hline 0,1 & 0,10 & 0 & 0,002625 & 0 \\
\hline 0,1 & 0,10 & 0 & 0,001875 & 0 \\
\hline 0,1 & 0,10 & 0 & 0,001625 & 0 \\
\hline 0,1 & 0,10 & 0 & 0,00375 & 0 \\
\hline 0,1 & 0,10 & 0 & 0,0015 & 0 \\
\hline 0,1 & 0,10 & 0 & 0,00125 & 0 \\
\hline 0,1 & 0,10 & 0 & 0,002 & 0 \\
\hline 0,1 & 0,10 & 0 & 0,001 & 0 \\
\hline 0,1 & 0,10 & 0 & 0,003875 & 0 \\
\hline 0,1 & 0,10 & 0 & 0,001375 & 0 \\
\hline 0,1 & 0,10 & 0 & 0,002125 & 0 \\
\hline 0,1 & 0,10 & 0 & 0,0015 & 0 \\
\hline 0,1 & 0,10 & 0 & 0,00175 & 0 \\
\hline 0,1 & 0,10 & 0 & 0,0015 & 0 \\
\hline 0,1 & 0,10 & 0 & 0,001875 & 0 \\
\hline 0,1 & 0,10 & 0 & 0,002 & 0 \\
\hline 0,1 & 0,10 & 0 & 0,001375 & 0 \\
\hline 0,1 & 0,10 & 0 & 0,00175 & 0 \\
\hline 0,1 & 0,10 & 0 & 0,001375 & 0 \\
\hline 0,1 & 0,10 & 0 & 0,002375 & 0 \\
\hline 0,1 & 0,10 & 0 & 0,001625 & 0 \\
\hline 0,1 & 0,10 & 0 & 0,001625 & 0 \\
\hline 0,1 & 0,10 & 0 & 0,002 & 0 \\
\hline 0,1 & 0,10 & 0 & 0,00238 & 0 \\
\hline 0,1 & 0,10 & 0 & 0,001125 & 0 \\
\hline 0,1 & 0,10 & 0 & 0,00175 & 0 \\
\hline 0,1 & 0,10 & 0 & 0,000625 & 0 \\
\hline 0,1 & 0,10 & 0 & 0,002875 & 0 \\
\hline 0,1 & 0,10 & 0 & 0,00125 & 0 \\
\hline 0,1 & 0,10 & 0 & 0,0015 & 0 \\
\hline 0,1 & 0,10 & 0 & 0,00175 & 0 \\
\hline 0,1 & 0,10 & 0 & 0,002375 & 0 \\
\hline 0,1 & 0,10 & 0 & 0,001875 & 0 \\
\hline 0,1 & 0,10 & 0 & 0,00075 & 0 \\
\hline 0,1 & 0,10 & 0 & 0,001125 & 0 \\
\hline 0,1 & 0,10 & 0 & 0,001375 & 0 \\
\hline 0,1 & 0,10 & 0 & 0,0015 & 0 \\
\hline 0,1 & 0,10 & 0 & 0,00038 & 0 \\
\hline 0,1 & 0,10 & 0 & 0,001375 & 0 \\
\hline 0,1 & 0,10 & 0 & 0,001375 & 0 \\
\hline 0,1 & 0,10 & 0 & 0,001 & 0 \\
\hline 0,1 & 0,10 & 0 & 0,001625 & 0 \\
\hline 0,1 & 0,10 & 0 & 0,00125 & 0 \\
\hline 0,1 & 0,10 & 0 & 0,001875 & 0 \\
\hline 0,1 & 0,10 & 0 & 0,004 & 0 \\
\hline 0,9 & 0,97 & 1 & 1,08875 & 1 \\
\hline 0,9 & 1,00 & 1 & 1,125 & 1 \\
\hline 0,9 & 1,00 & 1 & 1,125 & 1 \\
\hline 0,9 & 1,00 & 1 & 1,125 & 1 \\
\hline 0,9 & 1,00 & 1 & 1,125 & 1 \\
\hline
\end{tabular}




\begin{tabular}{|c|c|c|c|c|}
\hline 0,9 & 1,00 & 1 & 1,125 & 1 \\
\hline 0,9 & 1,00 & 1 & 1,125 & 1 \\
\hline 0,9 & 1,00 & 1 & 1,125 & 1 \\
\hline 0,9 & 1,00 & 1 & 1,125 & 1 \\
\hline 0,9 & 1,00 & 1 & 1,125 & 1 \\
\hline 0,9 & 1,00 & 1 & 1,125 & 1 \\
\hline 0,9 & 1,00 & 1 & 1,125 & 1 \\
\hline 0,9 & 1,00 & 1 & 1,125 & 1 \\
\hline 0,9 & 1,00 & 1 & 1,125 & 1 \\
\hline 0,9 & 1,00 & 1 & 1,125 & 1 \\
\hline 0,9 & 1,00 & 1 & 1,125 & 1 \\
\hline 0,9 & 1,00 & 1 & 1,125 & 1 \\
\hline 0,9 & 1,00 & 1 & 1,124625 & 1 \\
\hline 0,9 & 1,00 & 1 & 1,124875 & 1 \\
\hline 0,9 & 1,00 & 1 & 1,125 & 1 \\
\hline 0,9 & 1,00 & 1 & 1,125 & 1 \\
\hline 0,9 & 1,00 & 1 & 1,125 & 1 \\
\hline 0,9 & 1,00 & 1 & 1,125 & 1 \\
\hline 0,9 & 1,00 & 1 & 1,121125 & 1 \\
\hline 0,9 & 1,00 & 1 & 1,125 & 1 \\
\hline 0,9 & 1,00 & 1 & 1,125 & 1 \\
\hline 0,9 & 1,00 & 1 & 1,125 & 1 \\
\hline 0,9 & 1,00 & 1 & 1,12125 & 1 \\
\hline 0,9 & 1,00 & 1 & 1,1245 & 1 \\
\hline 0,9 & 1,00 & 1 & 1,1235 & 1 \\
\hline 0,9 & 1,00 & 1 & 1,124875 & 1 \\
\hline 0,9 & 1,00 & 1 & 1,124125 & 1 \\
\hline 0,9 & 1,00 & 1 & 1,125 & 1 \\
\hline 0,9 & 1,00 & 1 & 1,125 & 1 \\
\hline 0,9 & 1,00 & 1 & 1,125 & 1 \\
\hline 0,9 & 1,00 & 1 & 1,125 & 1 \\
\hline 0,9 & 1,00 & 1 & 1,125 & 1 \\
\hline 0,9 & 1,00 & 1 & 1,12325 & 1 \\
\hline 0,9 & 1,00 & 1 & 1,125 & 1 \\
\hline 0,9 & 1,00 & 1 & 1,125 & 1 \\
\hline 0,9 & 1,00 & 1 & 1,125 & 1 \\
\hline 0,9 & 1,00 & 1 & 1,125 & 1 \\
\hline 0,9 & 1,00 & 1 & 1,125 & 1 \\
\hline 0,9 & 1,00 & 1 & 1,125 & 1 \\
\hline 0,9 & 1,00 & 1 & 1,125 & 1 \\
\hline 0,9 & 1,00 & 1 & 1,124875 & 1 \\
\hline 0,9 & 1,00 & 1 & 1,12125 & 1 \\
\hline 0,9 & 1,00 & 1 & 1,125 & 1 \\
\hline 0,9 & 1,00 & 1 & 1,125 & 1 \\
\hline 0,9 & 1,00 & 1 & 1,125 & 1 \\
\hline
\end{tabular}

As seen in Table 4, the damage data were assessed as output data by coding it as 0 or 1 . While 0 represents a no damage policy whose litigation risk has not occurred, 1 represents a damaged policy whose litigation risk has occurred. The values in Table 4 show that the artificial neural network yielded very good results. The output values of the model were reached by rounding the normalized data of the artificial neural network model results using the Purelin option to the nearest 0,5 . The data from 99 (50 damaged and 49 no damage) of the 100 policies (50 damaged and 50 no damage) were assessed as test data and were forecasted accurately. As seen in the first line of Table 4, only 1 no damage policy was misestimated as damaged. After completing the testing stage, it was seen that the forecasting success of the risk assessment model developed with the artificial neural network was $99 \%$.

It can be argued that the litigation risk model yielded successful results because the artificial neural network model provided good training and test results. The error margin obtained at the stage of network training and testing was negligible. The policy data 
completed their training in the artificial neural network successfully. It was concluded that the results obtained in the study and in the artificial neural network model were very close to the actual values, which means that an artificial neural network can be used effectively to assess the risk of accounting professional liability insurance.

\section{Conclusion}

In the artificial neural network model, the litigation risk of 100 policies that were used as test data was predicted and the model achieved a 99\% accuracy rate. The results of the study showed that the probability of accurate forecasting was $99 \%$, whereas the inaccurate classification probability was $1 \%$. The model resulted in a high forecasting ability.

In the artificial neural network model, an insurance company can determine and assess the litigation risk factors in accounting professional liability insurance and the litigation risk of accounting professionals and can subsequently either not insure the highlitigation-risk insured or can ask for a high premium.

It is seen that insurance companies in Turkey have a simple insurance application form that does not evaluate many of the factors examined by insurance companies working internationally. Analyzing the application in Turkey, it is clear that the insurance application forms are not filled in properly; giving more importance to the insurance application forms might allow the risk to be more extensively assessed.

Analyzing the application forms of insurance companies in Turkey, it is seen that the company-specific risk factors are examined but the customer specific risk factors are not. The risk factor groups have not been formed in Turkey and the risk factors have been addressed narrowly. A database should be formed in case the data are unclassified or not recorded properly.

Questioning the customer-specific risk factors will enable a more extensive modeling for insurance companies when assessing the litigation risks. The insurance companies should include the customer specific litigation risk factors in the insurance application forms and pay attention to the assessment of these factors.

Risk assessment modeling will enable the insurance sector to determine its sales strategy. Thanks to risk assessment modeling, the policy holder with high litigation risk will be separated from the policy holder with low litigation risk. The insurance companies will develop a sales strategy in which they will insure low litigation risk but will either turn down high litigation risk or will determine higher premiums for it. Developing the right sales strategy will allow the appropriate customer portfolio to be determined and the appropriate decisions to be made. The insurance company can foresee the damage caused by the risk 
either by rejecting the highly risky insured or by demanding higher premiums, thus providing compensation promptly and efficiently.

\section{References}

Bonner, S.E. \& Z. Palmrose \& S.M. Young (1998), "Fraud Type and Auditor Litigation: An Analysis of SEC Accounting and Auditing Enforcement Releases", The Accounting Review, 73, 503-532.

Carcello, J.V. \& Z. Palmrose (1994), "Auditor Litigation and Modified Reporting on Bankrupt Clients", Journal of Accounting Research, 32, 1-30.

Craig, F.L. (1995), "With Neural Networks, Computers do More than Just Follow Orders”, The Michigan CPA, Summer, 47(1), 9.

Dorfman, M.S. (1991), Introduction to Risk Management and Insurance, Prentice-Hall Inc., NJ.

Ellacott, S. \& D. Bose (1996), Neural Networks: Deterministic Methods of Analyis, International Thomson Computer Press, London.

Fausett, L.V. (1994), Fundamentals of Neural Networks: Architectures, Algorithms, and Application, Prentice-Hall Inc., NJ.

Ferguson, M.J. \& A. Majid (2003), "To Sue or Not to Sue: An Experimental Study of Factors Affecting Hong Kong Liquidators Audit Litigation Decisions", Journal of Business Ethics, 46, 363-374.

Francis, J. \& D. Philbrick \& K. Schipper (1998), "Earnings Surprises and Litigation Risk", Journal of Financials Statement Analysis, 3(2), 15-27.

He, H. \& J. Wang \& W. Graco \& S. Hawkins (1997), “Application of Neural Networks to Detection of Medical Fraud”, Expert Systems with Applications, 13(4), 329-336.

Hsu, S. \& C. Lin \& Y. Yang (2008), "Integrating Neural Networks for Risk-Adjustment Models”, Journal of Risk and Insurance, 75(3), 617-642.

Ismael, M.B. (1999), "Prediction of mortality and in-hospital complications for acute myocardial infarction patients using artificial neural networks", Ph.D. Dissertation, Duke University, $\mathrm{NC}$.

Jablonoeski, M. (1998), “Automating the Risk Assessment Process”, CPCU Journal, 51(2), 101-107.

Lin, C. (2009), "Using Neural Networks as a Support Tool in the Decision Making for Insurance Industry", Expert Systems with Applications, 36, 6914-6917.

Linville, M. (2001), "The Effects of State Tort Provisions and Perceptions of Litigation Risk On Malpractice Insurance”, Journal of Applied Business Research, 17(3), 61-71.

Linville, M. \& J. Thornton (2001), "Litigation Risk Factors As Identified By Malpractice Insurance Carriers", Journal of Applied Business Research, 17(4), 93-105.

Lowe, J. \& L. Pryor (1996), "Neural Network v. GLMs in Pricing General Insurance”, 1996 General Insurance Convention, 1, 417-438.

Lys, T. \& R. Watts (1994), “Lawsuits Againts Auditors”, Journal of Accounting Research, 32, 6593.

Paliwal, M. \& U.A. Kumar (2009), "Neural Networks and Statistical Techniques: A Review of Applications", Expert Systems with Applications, 36, 2-17. 
Palmrose, Z. (1987), "Litigation and Independent Auditors: The Role of Business Failures and Management Fraud", Auditing: A Journal of Practice \& Theory, 6(2), 90-103.

Schultz, J.J. \& S.G. Gustavson (1978), “Actuaries' Perceptions of Variables Affecting the Independent Auditor's Legal Liability”, The Acoounting Rewiew, 3, 626-641.

Shah, P. \& A. Guez (2009), "Mortality Forecasting Using Neural Networks and an Application to Cause-Specific Data for Insurance Purposes", Journal of Forecasting, 28(6), 535-548.

Shapiro, A.F. (2002), "The Merging of Neural Networks, Fuzzy Logic and Genetic Algorithms", Insurance. Mathematics and Economics, 31(1), 115-131.

Shapiro, A.F. \& L.C. Jean (2003), Intelligent and Other Computational Techniques in Insurance: Theory and Applications, World Scientific Publishing, Danvers.

Shapiro, L.E. (2004), "Professional Liability Insurance", Ashrae Journal, 46(10), 59-60.

Simunic, D.A. \& M.T. Stein (1996), "The Impact of Litigation Risk on Audit Pricing: A Review of the Economics and the Evidence", Auditing: A Journal of Practice \& Theory, 15, 119134.

Smith, K.A. \& R.J. Willis \& M. Brooks (2000), “An Analysis of Customer Retention and Insurance Claim Patterns Using Data Mining: A Case Study", The Journal of the Operational Research Society, 51(5), 532-541.

Stice, J.D. (1991), “Using Financial and Market Information to Identify Pre-Engagement Factors Associated with Lawsuits Against Auditors", The Accounting Review, 56(3), 516-533.

St. Pierre, K. \& J.A. Anderson (1984), “An Analysis of the Factors Associated with Lawsuits against Public Accountants", The Accountant Review, 2, 242-263.

Tauhet, C. (1997), “Neural Networks: Not Just A Black Box”, Insurance \& Technology, 22(4), 3032.

Trippi, R.R. \& E. Turban (1996), Neural Networks in Finance and Investing, Irwin Publishing, Chicago.

TSRŞB (2010), Mesleki Sorumluluk Sigortası Genel Şartları [General Conditions for Accounting Professional Liability Insurance], <http://tsrsb.org.tr/sayfa/mesleki-sorumluluk-sigortasigenel-sartlari>, 16.7.2010.

Vaughan, E.J. \& T. Vaughan (2007), Fundamentals of Risk and Insurance, John Wiley \& Sons, Inc., NJ.

Vaugh, M. \& E. Ong \& S.J. Cavill (1997), "Interpretation and Knowledge Discovery from a Multilayer Perceptron Network that Performs Whole Life Assurance Risk Assesment", Neural Computing Applications, 6, 201-213.

Yeo, A.C. \& K.A. Smith \& R.J. Willis \& M. Brooks (2002), “A Mathematical Programming Approach to Optimise Insurance Premium Pricing within a Data Mining Framework", The Journal of the Operational Research Society, 53(11), 1197-1203.

Yıldız, B. (2001), "Prediction of Financial Failure with Artificial Neural Network Technology and an Emprical Application on Publicly Held Companies", ISE Review, 5(17), 47-62. 